\title{
ANALISIS KEBUTUHAN OKSIGEN UNTUK DEKOMPOSISI BAHAN ORGANIK SEDIMEN DI KAWASAN MANGROVE DESA BEDONO DEMAK
}

\author{
Analysis of Oxygen Demand For Decomposition Sediment Organic Matter \\ In Bedono Village Area Mangrove, Demak
}

\author{
Mia Arista Sari, Pujiono Wahyu Purnomo*), Haeruddin
}

Program Studi Manajemen Perairan, Jurusan Perikanan

Fakultas Perikanan dan Ilmu Kelautan, Universitas Diponegoro

Jl. Prof. Soedarto, SH, Tembalang, Semarang, Jawa Tengah - 50275, Telp/Fax. +62247474698

Email: mia_ariesta@yahoo.co.id

\begin{abstract}
ABSTRAK
Salah satu peran penting mangrove bagi kehidupan biota akuatik adalah sebagai penyedia nutrien dari bahan organik yang dihasilkan. Proses dekomposisi bahan organik membutuhkan oksigen dan bantuan bakteri. Apabila kadar oksigen berkurang maka dapat mempengaruhi proses dekomposisi dan akhirnya dapat berpengaruh terhadap kehidupan bentos yang ada. Tujuan dari penelitian adalah mengetahui kebutuhan oksigen yang digunakan dalam proses dekomposisi bahan organik pada kawasan mangrove. Penelitian bersifat eksperimental terhadap deposit bahan organik. Penelitian mengacu pada rancangan acak lengkap dengan 3 perlakuan (deposit organik mangrove padat, sedang, dan jarang) yang masing - masing diulang 3 kali. Penelitian dilakukan di kawasan mangrove desa Bedono, Demak. Peubah utama yang diukur adalah Disolved Oxygen, bahan organik sedimen secara berkala pada jam ke- $0,12,24,36,48,60$ dan 66. Peubah tambahan yang diukur adalah kelimpahan bakteri. Diukur penurunan Disolved Oxigen pada waktu tertentu. Diukur pula nilai bahan organik sedimen dan kelimpahan koloni bakteri. Hasil yang didapat yaitu nilai kebutuhan oksigen sedimen tertinggi pada stasiun 1 dengan kisaran 1,3 - 3,5. Nilai kebutuhan oksigen sedimen pada stasiun 2 berkisar antara 1,22,2 dan nilai kebutuhan oksigen sedimen pada stasiun 3 berkisar antara $0,8-2,7$. Hasil kelimpahan koloni bakteri pada stasiun 1 berkisar antara $1 \times 10^{11}-1,5 \times 10^{11} \mathrm{Cfu} / \mathrm{ml}$. Stasiun 2 berkisar antara $2 \times 10^{11}-22 \mathrm{x}$ $10^{11} \mathrm{Cfu} / \mathrm{ml}$ dan stasiun 3 berkisar antara $1 \times 10^{11}-2 \times 10^{11} \mathrm{Cfu} / \mathrm{ml}$. Kualitas perairan seperti temperatur berikisar antara $27-32^{\circ} \mathrm{C}$. Nilai salinitas beriksar antara 25 - 29\%o dan nilai pH berkisar antara 7 - 8 .
\end{abstract}

Kata kunci: Oksigen; Bahan Organik; Sedimen; Dekomposisi

\begin{abstract}
One important role of mangrove for aquatic biota is a provider of nutrients from organic matter produced. The process of decomposition of organic matter need oxygen and help the bacteria. When oxygen levelsdecreases, it can affect the decomposition process and can ultimately affect the existing benthic life. The purpose of the research was to determine the need of oxygen used in the decomposition of organic matter in the mangrove areas. It is a experimental research on the deposit of organic material. The research refers to a completely randomized design with 3 treatments (dense mangrove organic deposits, medium, and rare) that eachs repeated three times. Research conducted in the mangrove areas Bedono village, Demak. The main variables measured were Disolved Oxygen, sedimentary organic matter on a regular basis on the hour 0, 12, 24, 36, 48, 60 and 66. Additional variables that measured the abundance of bacteria.MeasuredDisolvedOxigen decline at a certain time. Measured the value of sedimentary organic matter and the abundance of bacterial colonies. The result is the highest value of the oxygen requirement of sediment at station 1 is in the range of 1,3 to 3,5. The value of the oxygen requirement of sediment at station 2 ranged from 1,2 to 2,2 and the value ofsediment oxygen demand of the three stations ranged from 0,8 to 2,7. The result of the abundance of bacteria colonies from the at station 1 range from $1 \times 10^{11}$ to $1,5 \times 10^{11} \mathrm{Cfu} / \mathrm{ml}$. Station 2 ranging from $2 \times 10^{11}-22 \times 10^{11} \mathrm{Cfu} / \mathrm{ml}$ and three stations ranged between $1 \times 10^{11}-2 \times 10^{11} \mathrm{Cfu} / \mathrm{ml}$. Water quality such as temperature ranged from $27-32{ }^{\circ} \mathrm{C}$. Salinity value ranged from $25-29 \%$ and $\mathrm{pH}$ values ranged from 7-8.
\end{abstract}

Keywords: Oxygen; Organic Matter; Sediment; Decompotition

\section{PENDAHULUAN}

Kawasan mangrove merupakan salah satu kawasan penting di daerah pantai, muara dan sungai. Dimaksud kawasan penting karena mangrove memiliki manfaat baik secara ekonomi maupun ekologi. Manfaat 
secara ekologi yaitu sebagai tempat perlindungan, pemijahan biota, dapat menghambat arus atau gelombang yang menuju arah pantai, menghambat atau memperlambat hembusan angin ke arah pantai, sebagai sedimen trap, dan mengurangi abrasi.

Ekosistem ini memiliki peranan ekologi, sosial-ekonomi, dan sosia-budaya yang sangat penting; misalnya menjaga menjaga stabilitas pantai dari abrasi, sumber ikan, udang dan keanekaragaman hayati lainnya, sumber kayu bakar dan kayu bangunan, serta memiliki fungsi konservasi, pendidikan, ekoturisme dan identitas budaya (Setyawan dan Winarno, 2006).

Arus yang berasal dari laut membawa partikel - partikel yang mengandung bahan organik terjaring atau terperangkap pada akar - akar sedimen. Bahan organik ini dapat dimanfaatkan oleh biota - biota bentos sebagai bahan makanan. Selain itu bahan organik ini juga dapat berasal dari daun - daun mangrove yang jatuh dan terjadi proses dekomposisi oleh bakteri.

Unsur hara yang dihasilkan dari proses dekomposisi serasah di dalam tanah sangat penting dalam pertumbuhan mangrove dan sebagai sumber nutrien bagi ekosistem laut dan estuari dalam menyokong kehidupan berbagai organisme akuatik. Apabila serasah di hutan mangrove ini diperkirakan dengan benar dan dipadukan dengan perhitungan biomassa lainnya, akan diperoleh informasi penting dalam produksi, dekomposisi, dan siklus nutrisi ekosistem hutan mangrove. Analisis komposisi hara pada produksi serasah dapat menunjukkan potensi nutrisi (hara) yang digunakan, yang dihasilkan pada ekosistem hutan mangrove (Zamroni dan Rohyani, 2008).

Produksi nutrien ini salah satunya berasal dari proses dekomposisi dari bakteri yang ada di sedimen, yang mengurai daun - daun mangrove yang jatuh dengan bantuan oksigen. Maka atas dasar hal tersebut daerah mangrove merupakan daerah yang kaya akan bahan organik. Kurangnnya kadar oksigen di sedimen makan akan berpengaruh terhadap bakteri yang akan melakukan proses dekomposisi.

Penelitian tentang kebutuhan oksigen pada sedimen menggambarkan jumlah energi yang dibutuhkan untuk merombak bahan organik. Mengingat oksigen merupakan energi utama untuk merombak bahan organik menjadi unsur hara di lingkungan sekitarnya, maka perlu ditelaah dan dikaji lagi mengenai kebutuhan oksigen sedimen di pada tingkat kerapatan mangrove yang berbeda.

\section{MATERI DAN METODE PENELITIAN}

A. Materi Penelitian

Materi penelitian ini terdiri atas alat dan bahan. Alat yang digunakan untuk sampling lapangan yaitu refraktometer, bola arus, pH meter, GPS (Global Positioning System), jerigen $50 \mathrm{ml}$, plastik besar hitam, kamera dan alat tulis. Alat yang digunakan untuk penelitian analisis kebutuhan oksigen sedimen yaitu akuarium 18 buah, aerator, DO meter, $\mathrm{pH}$ meter dan refraktometer. Alat yang digunakan untuk penelitian bahan organik sedimen yaitu oven, alumunium foil, loyang, mortar alu, timbangan elektrik, dan furnace. Alat yang digunakan untuk penelitian kelimpahan koloni bakteri yaitu erlenmeyer $1000 \mathrm{ml}$, hot plate, gelas beaker, tabung reaksi, pipet $2 \mathrm{ml}$ dan pipet gondod, mikropipet, dan cawan petridish.

Bahan yang digunakan saat sampling lapangan dan analisis kebutuhan oksigen sedimen yaitu air laut dan sedimen dari kawasan mangrove Desa Bedono sebagai bahan yang akan diteliti, akuades untuk kalibrasi alat seperti DO meter dan salinometer. Bahan yang digunakan untuk pengukuran bahan organik sedimen yaitu media agar PCA (Plate Count Agar) sebagai media pertumbuhan bakteri, $\mathrm{KCl}, \mathrm{MgSO}_{4}$ dan $\mathrm{NaCl}$ sebagai media membuat larutan trisalt untuk pengenceran.

\section{B. $\quad$ Metode Penelitian}

Penelitian ini menggunakan metode eksperimental di laboratorium pada perbedaan tiga tipe kerapatan mangrove di desa Bedono. Metode pengambilan sampel dilakukan secara acak.

a. Lokasi Sampling

Lokasi sampling adalah ekosistem mangrove di Desa Bedono, Sayung, Demak. Dalam hal ini dilakukan pada tiga titik dengan kerapatan yang berbeda. Perbedaan titik sampling ini diperkirakan terdapat perbedaan tinggi rendahnya bahan organik dari proses dekomposisi dari serasah yang jatuh, untuk selanjutnya dijadikan sebagai perlakuan. Titik sampling tersebut adalah sebagai berikut:

Stasiun 1.

$\mathrm{S}=06^{\circ} 54^{\prime} 86^{\prime \prime}$

$\mathrm{E}=110^{\circ} 29^{\prime} 23^{\prime \prime}$ (Kerapatan mangrove paling tinggi)

Stasiun 2

$\mathrm{S}=06^{\circ} 54^{\prime} 98^{\prime \prime}$

Stasiun 3

$\mathrm{E}=110^{\circ} 28^{\prime} 92^{\prime \prime}$ (Kerapatan mangrove sedang)

$\mathrm{S}=06^{\circ} 55^{\prime} 48^{\prime \prime}$

$\mathrm{E}=110^{\circ} 28^{\prime} 71^{\prime \prime}$ (Kerapatan mangrove rendah) 


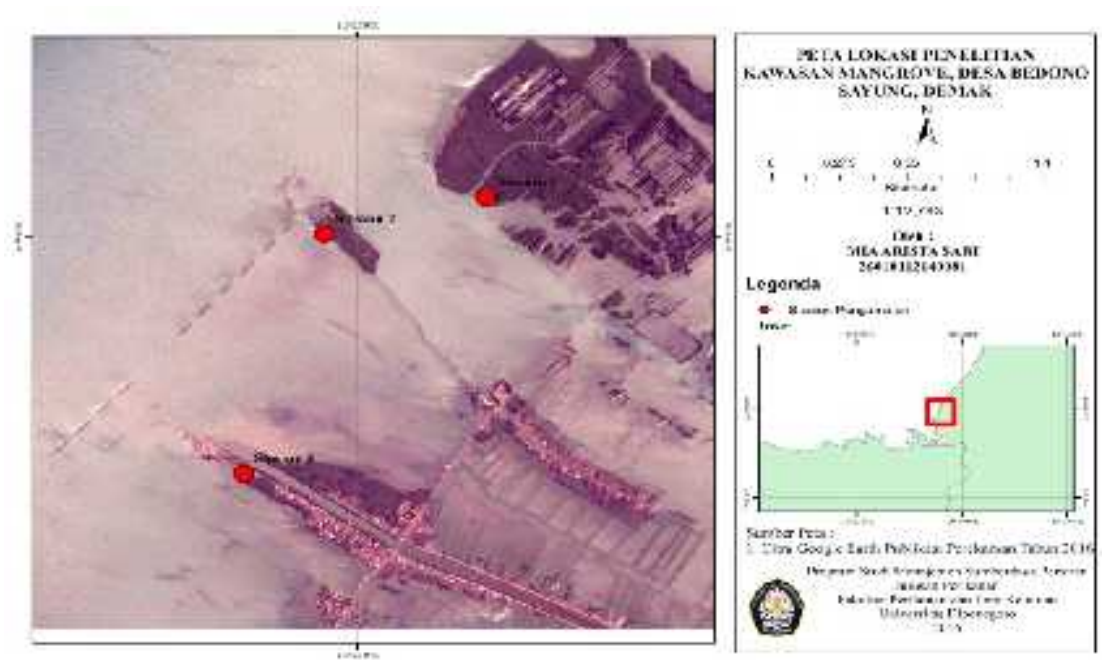

b.

Gambar 1. Peta Lokasi Penelitian

beknik Pengambilan Sampel Sedimen

Contoh air diambil yang berada dekat sedimen, kemudian contoh air yang telah diambil dimasukkan ke dalam jerigen plastik yang telah diberi label. Contoh sedimen diambil langsung menggunakan pipa sedimen yang telah diberi pegangan. Contoh sedimen yang diperoleh dimasukkan ke dalam plastik yang telah diberi label, kemudian dibungkus dengan plastik berwarna gelap dan disimpan ke dalam kotak (cool box) yang telah diberi es batu untuk segera diangkut ke laboratorium (Hadinafta, 2009).

c. Rancangan Percobaan

Terdapat 3 stasiun, dimana setiap stasiun terdapat 3 pengulangan. Rancangan percobaan ini menggunakan Rancangan Acak Lengkap (RAL). Menurut Siska dan Salam (2012), rancangan acak lengkap adalah desain di mana perlakuan dikenakan sepenuhnya secara acak kepada unit-unit eksperimen, atau sebaliknya. Dengan demikian tidak terdapat batasan terhadap pengacakan seperti misalnya dengan adanya pemblokan dan pengalokasian perlakuan terhadap unit-unit eksperimen. Berikut Rancangan Acak Lengkap (RAL) pada uji analisis kebutuhan oksigen sedimen.

Tabel 1. Tabel Rancangan Acak Lengkap (RAL)

\begin{tabular}{lllll}
\hline & K & S1 & S2 & S3 \\
\hline U1 & KU1 & S1U1 & S2U1 & S3U1 \\
U2 & KU2 & S1U2 & S2U2 & S3U2 \\
U3 & KU3 & S1U3 & S2U3 & S3U3 \\
\hline
\end{tabular}

Keterangan:

S1 : Stasiun 1

S2 : Stasiun 2

S3 : Stasiun 3

U1 : Pengulangan 1

U2 : Pengulangan 2

U3 : Pengulangan 3

K : Kontrol

d. Analisis Kebutuhan Oksigen Sedimen

Pengamatan analisis kebutuhan oksigen sedimen di laboratorium Pengembangan Sumberdaya Ikan dan Lingkungan menggunakan metode sesuai yang dilakukan oleh Hadinafta (2009), yaitu sebagai berikut:

Terdapat 2 tahapan yaitu pada tahap 1, akuarium I hanya diisi dengan contoh air saja. Contoh air dimasukkan ke dalam akuarium setinggi $20 \mathrm{~cm}$. Untuk tahapan 2, akuarium II terlebih dahulu diisi dengan sedimen setinggi $10 \mathrm{~cm}$ kemudian dimasukkan contoh air secara perlahan setinggi $20 \mathrm{~cm}$. Untuk menghindari terjadinya penambahan oksigen akibat proses fotosintesis, pengamatan dilakukan di ruang tertutup dan semua akuarium pengamatan ditutup dengan plastik berwarna hitam.

Kemudian diukur penggunaan oksigen menggunkan DO meter. Frekuensi pengukuran akan ditambah pada hari dimana jumlah oksigen akan habis atau mendekati nol, yaitu pada jam ke- 0, 12, 24, 36, 48, 60, dan 66. Kebutuhan oksigen adalah nilai slope pada perlakuan DO awal hingga nol selama masa penelitian dibagi selisih kadar bahan organik.

$\mathrm{KUS}=\frac{\Delta \mathrm{DU}}{\Delta \mathrm{BU}}$ 
Keterangan:

KOS = Kebutuhan Oksigen Sedimen

DO = Selisih Dissolved Oxygen dari jam ke- 0 sampai jam ke- 66

BO = Selisih Bahan Organik dari jam ke-0 sampai jam ke- 66

e. Analisis Bahan Organik Sedimen

Analisis TOM diukur setiap 24 jam sekali (setiap hari) untuk akuarium II atau akuarium yang berisi air dan sedimen, menggunakan prinsip gravimetri (Sudjadi, et al. dalam Roswati, 2014 ) adalah sebagai berikut:

1. Sampel tanah diambil sekitar $20 \mathrm{ml}$, kemudian dikeringkan dalam oven dengan temperatur $60^{\circ} \mathrm{C}$ selama 24 jam hingga kering dan dapat digerus.

2. Sampel tanah yang telah kering digerus dengan porcelain grinder hingga halus kemudian dimasukkan ke dalam oven hingga kering benar (kurang lebih selama dua jam).

3. Setelah tanah kering mutlak, ditimbang sekitar 5 gram dan ditampung dalam cawan porcelain dengan volume $25 \mathrm{ml}$, yang kemudian dibakar dengan alat pengabuan (furnace) yang temperaturnya mencapai $550^{\circ} \mathrm{C}$ selama 5 jam. Selisih berat antara sampel kering sebelum dibakar dianggap bahan organik yang hilang, kadar bahan organik total dihitung dengan rumus:

Bahan Organik Total $=\frac{W t-C-(W a-C)}{w t-c} \times 100$

Keterangan : $\quad \mathrm{Wt}=$ berat total $($ crucible + sampel $)$ sebelum dibakar

$\mathrm{Wa}=$ berat total (crucible + sampel) setelah dibakar

$\mathrm{C} \quad=$ berat crucible kosong

\section{f. Analisis Kelimpahan Koloni Bakteri}

Analisis kelimpahan bakteri yang ada di sedimen menurut Putri (2015) menggunakan pengujian Total Plate Count (TPC), yaitu Plate Count Agar (PCA) ditimbang sebanyak 11,25 gram, dimasukkan ke dalam tabung Erlenmeyer dan dilarutkan (dihomogenasi) dengan akuades sebanyak $500 \mathrm{ml}$, kemudian dipanaskan di atas hot plate sampai mendidih, tutup disterilisasi dengan autoclave pada temperatur $121{ }^{\circ} \mathrm{C}$ selama 15 menit. Selanjutnya pembuatan larutan Trisalt dengan cara mencampur KCL 0,30 gr, MgSO4 2,78 gr, dan NaCl 9,36 gr dengan aquades $400 \mathrm{ml}$.

Pengenceran sampel dengan cara sedimen basah ditimbang 1 gram. Tabung reaksi disiapkan 4 buah dan diberi label $10^{-1}, 10^{-2}, 10^{-3}$ sampai $10^{-7}$. Larutan Trisalt dimasukkan ke dalam masing - masing tabung reaksi. Sedimen yang telah ditimbang dimasukkan kedalam tabung $10^{-1}$ (dihomogenkan dengan cara digojog). Sebanyak $1 \mathrm{ml}$ larutan dari tabung $10^{-1}$ diambil dengan mikropipet, dimasukkan ke dalam tabung $10^{-2}$ (dihomogenkan) dan seterusnya sampai $10^{-7}$.

Perhitungan jumlah koloni bakteri, yaitu dengan menghitung jumlah koloni pada setiap seri pengenceran kecuali cawan petridish yang berkoloni menyebar. Cawan petridish yang dipilih adalah mempunyai jumlah koloni 25 sampai 250. Hasil perhitungan yaitu 1 x $10^{7} \mathrm{CFU} / \mathrm{ml}$ untuk TPC. Pengukuran kelimpahan koloni bakteri dilakukan setiap 24 jam sekali (setiap hari) pada akuarium II atau akuarium yang berisi air dan sedimen. Kemudian dimasukan kedalam perhitungan rumus kelimpahan koloni bakteri, yaitu:

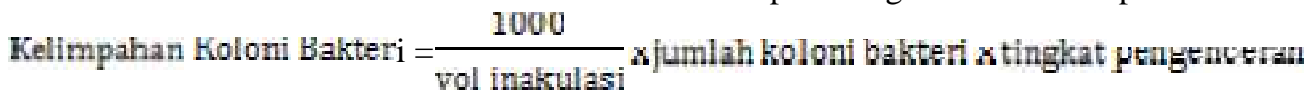

\section{g. Analisis Data}

Data yang diperoleh pada pengukuran di analisis menggunakan uji parametrik yaitu Uji ANOVA (Analysis of Variance) model One Way. Analisis data untuk mengetahui perbedaan respon perubahan yang diuji seperti nilai Dissolved Oxygen, kebutuhan oksigen sedimen, bahan organik. Sebelum uji ANOVA, terlebih dahulu dilakukan uji normalitas dan uji homogenitas untuk mengatahui apakah data tersebut sudah normal dan homogen. Namun bila data tidak homogen dapat menggunakan uji non parametrik. Selanjutnya Uji ANOVA dengan hipotesis Uji:

H0 $\quad=\mu=\mu=$ tidak terdapat perbedaan pada nilai Dissolved Oxygen, kebutuhan oksigen sedimen, bahan organik setiap perlakuan

H1 $\quad=\mu \neq \mu=$ terdapat perbedaan pada nilai Dissolved Oxygen, kebutuhan oksigen sedimen, bahan organik setiap perlakuan

Terima H0, tolak H1 jika F dihitung $\leq \mathrm{F}$ Tabel pada taraf $\alpha 0,05$

Tolak H0, terima H1 jika F dihitung > F Tabel pada taraf $\alpha 0,05$ 
3. HASIL DAN PEMBAHASAN

A. Hasil

a. Deskripsi Lokasi

Stasiun 1 berada daerah tracking mangrove. Daerah ini memiliki mangrove yang lebat dan hijau. Stasiun 1 ini memiliki kerapatan paling tinggi dibanding stasiun yang lainnya, berada daerah tracking mangrovedansering digunakan untuk wisata, sehingga hampir setiap hari ada perahu yang melewati daerah ini, memilikikerapatan paling tinggi dibanding stasiun yang lainnya, terdapat beberapa sampah akibat aktivitas pengunjung yang sering datang ke daerah tersebut, substrat berwarna hitam.

Stasiun 2 berada disebelah barat stasiun1. Stasiun 2 memiliki kerapatan yang hampir sama dengan stasiun 1, terdapat beberapa rumah penduduk penjaga makam, sehinggaterdapatsampah yang berasaldarirumahpenduduk, merupakandaerah yang terkadangdigunakannelayanuntukmencariikan, substrat berwarna hitam kecoklatan dan lebih encer dari stasiun 1.

Terakhir stasiun 3 berada daerah di sebelah barat muara sungai Sayung, memiliki kerapatan mangrove palilng rendah, jumlah pohon mangrove sedikit dan ada beberapa yang daunnya sudah kering dan layu, selain itu bebrapa pohon terlihat ada yang patah, substrat berawarna hitam kecoklatan namun tidak terlalu encer.

\section{b. Kebutuhan Oksigen Sedimen}

Kebutuhan oksigen sedimen merupakan oksigen yang digunakan dalam proses dekomposisi bahan organik sedimen. Prinsipnya adalah DO yang dibutuhkan untuk proses dekomposisi bahan organik, dimana nilai DO yang terpakai pada setiap nilai bahan organik yang didapat. Hasil uji terhadap oksigen terlarut menggunakan analisis Uji Anova Single Factor diperoleh keterangan bahwa antar stasiun berbeda nyata, $(\alpha)$ 0,05 . Berikut hasil pengukuran jumlah oksigen terlarut untuk proses dekomposisi bahan organik di kawasan mangrove.

Tabel 2. Jumlah Oksigen Terlarut untukProses Dekomposisi Bahan Organik Sedimen

\begin{tabular}{lllll}
\hline Pengulangan & Kontrol & Stasiun $\mathbf{1}(\mathbf{m g} / \mathbf{l})$ & Stasiun 2 $(\mathbf{m g} / \mathbf{l})$ & Stasiun $3(\mathbf{m g} / \mathbf{l})$ \\
\hline 1 & 1,99 & 6,6 & 7,49 & 5,39 \\
2 & 1,15 & 8,1 & 6,16 & 3,1 \\
3 & 3,03 & 5,41 & 4,48 & 4,63 \\
\hline Rerata: & 2,06 & 6,70 & 6,04 & 4,37 \\
SD: & 0,94 & 1,35 & 1,51 & 1,17 \\
\hline
\end{tabular}

Kadar oksigen seperti diperlihatkan pada Tabel 2 adalah jumlah oksigen untuk kebutuhan perombakan bahan organik. Nilai tersebut merupakan pengurangan nilai awal hingga terjadi kadar DO mencapai 0 mg/L. Terkait dengan hal tersebut maka dilakukan pengukuran terhadap jumlah bahan organik sedimen yang terdekomposisi. Hasil uji terhadap nilai bahan organik menggunakan analisis Uji Anova Single Factor diperoleh keterangan bahwa antar stasiun tidak berbeda, $(\alpha)$ 0,05. Hasilnya adalah tersaji pada Tabel 3.

Tabel 3. Hasil Bahan Organik Sedimen dalam Proses Dekomposisi di Kawasan Mangrove

\begin{tabular}{cccc}
\hline Pengulangan & Stasiun 1 $(\boldsymbol{\%})$ & Stasiun 2 $(\boldsymbol{\%})$ & Stasiun 3 $(\boldsymbol{\%})$ \\
\hline 1 & 2,4 & 5,6 & 2 \\
2 & 2,3 & 2,8 & 3,7 \\
3 & 3,9 & 3,7 & 5,2 \\
\hline Rerata: & 2,87 & 4,03 & 3,63 \\
SD: & 0,90 & 1,43 & 1,60
\end{tabular}

Selanjutnya setelah diketahui nilai DO dan bahan organik maka dapat diketahui nilai kebutuhan oksigen yang digunakan dalam proses dekomposisi bahan organik di kawasan mangrove. Nilai ini diapat dari penurunan nilai DO tiap penurunan bahan organik. Hasil uji terhadap kebuthan oksigen sedimen menggunakan analisis Uji Anova Single Factor diperoleh keterangan bahwa antar stasiun tidak berbeda, $(\alpha) 0,05$. Berikut hasil nilai kebutuhan oksigen yang digunakan untuk proses dekomposisi bahan organik sedimen tersaji pada Tabel 4 . 
Tabel 4. Nilai Kebutuhan Oksigen Sedimen untuk Proses Dekomposisi Bahan Organik di Kawasan Mangrove

\begin{tabular}{cccc}
\hline Pengulangan & Stasiun $\mathbf{1}$ & Stasiun $\mathbf{2}$ & Stasiun $\mathbf{3}$ \\
\hline 1 & 2,75 & 1,34 & 2,70 \\
2 & 3,52 & 2,20 & 0,84 \\
3 & 1,39 & 1,21 & 0,89 \\
\hline Rerata: & 2,55 & 1,58 & 1,47 \\
SD: & 1,08 & 0,54 & 1,06 \\
\hline
\end{tabular}

\section{c. Kelimpahan Koloni Bakteri}

Perhitungan koloni bakteri dilakukan pada semua stasiun setiap harinya. Berikut Tabel hasil kelimpahan koloni bakteri tersaji pada Tabel 5 .

Tabel 5. Kelimpahan Koloni Bakteri untuk Proses Dekomposisi Bahan Organik

\begin{tabular}{cccc}
\hline & Stasiun 1 (CFU/ml) & Stasiun 2 $($ CFU/ml $)$ & Stasiun 3 (CFU/ml) \\
\cline { 2 - 4 } Jam ke-0 & $2 \times 10^{11}$ & $44 \times 10^{11}$ & $2 \times 10^{11}$ \\
Jam ke-24 & $2 \times 10^{11}$ & $123 \times 10^{11}$ & $3 \times 10^{11}$ \\
Jam ke-48 & $3 \times 10^{11}$ & $4 \times 10^{11}$ & $4 \times 10^{11}$ \\
\hline Rerata: & $2,33 \times 10^{11}$ & $57 \times 10^{11}$ & $3 \times 10^{11}$ \\
SD: & 2,44 & 60,6 & 1 \\
\hline
\end{tabular}

d. $\quad$ Variabel Fisika dan Kimia Air

Hasil pengukuran temperatur, salinitas dan $\mathrm{pH}$ air dalam akuarium tersaji pada Tabel 6.

Tabel 6. Hasil Pengukuran Temperatur, Salinitas dan $\mathrm{pH}$ air dalam akuarium

\begin{tabular}{|c|c|c|c|c|c|}
\hline Jam ke- & Stasiun & Perlakuan & $\begin{array}{c}\text { Temperatur } \\
\left({ }^{\circ} \mathrm{C}\right)\end{array}$ & Salinitas (\%o) & $\mathrm{pH}$ \\
\hline \multirow[t]{6}{*}{0} & 1 & 1 & 32 & 27 & 7 \\
\hline & & 2 & 32 & 25 & 7 \\
\hline & 2 & 1 & 32 & 26 & 7 \\
\hline & & 2 & 32 & 26 & 7 \\
\hline & 3 & 1 & 32 & 28 & 7 \\
\hline & & 2 & 32 & 28 & 7 \\
\hline \multirow[t]{6}{*}{24} & 1 & 1 & 30 & 27 & 7 \\
\hline & & 2 & 30 & 27 & 7 \\
\hline & 2 & 1 & 30 & 28 & 7 \\
\hline & & 2 & 30 & 28 & 7 \\
\hline & 3 & 1 & 30 & 28 & 8 \\
\hline & & 2 & 29 & 29 & 8 \\
\hline \multirow{6}{*}{48} & 1 & 1 & 28 & 28 & 8 \\
\hline & & 2 & 29 & 27 & 7 \\
\hline & 2 & 1 & 28 & 30 & 8 \\
\hline & & 2 & 28 & 29 & 8 \\
\hline & 3 & 1 & 28 & 29 & 7 \\
\hline & & 2 & 27 & 28 & 7 \\
\hline Rerata: & & & 29,94 & 27,67 & 7,28 \\
\hline SD: & & & 1,73 & 1,24 & 0,46 \\
\hline
\end{tabular}

\section{B. Pembahasan}

a. Kebutuhan Oksigen Sedimen

Oksigen dalam periaran tidak hanya terdapat dalam air namun terdapat dalam sedimen. Oksigen disekitar sedimen ini nantinya digunakan oleh bakteri untuk merombak bahan organik sedimen. Oksigen merupakan salah satu faktor pembatas dalam proses dekomposisi bahan organik. Hasil penelitian menjukan berkurangnya nilai DO setiap harinya. Sehingga kebutuhan oksigen yang diperlukan semakin bertambah. Hal ini diperkuat oleh MacPherson (2003), bahwa hilangnya oksigen di perairan terjadi selama di kolom air karena dekomposisi bahan organik dan oksigen cepat masuk ke sedimen. Berkurangnya bahan organik oleh bakteri, oksidasi amonia oleh nitrifikasi, respirasi alga dan aliran oksigen ke dalam sedimen semua meningkatkan kebutuhan oksigen.

\footnotetext{
${ }^{\circledR}$ Copyright by Management of Aquatic Resources (MAQUARES)
} 
Nilai bahan organik mengalami fluktuasi, baik untuk stasiun 1, stasiun 2 ataupun stasiun 3. Fluktuasi ini dikarenakan masukan serasah yang berbeda pada setiap stasiun. Namun berdasarkan hasil yang didapat nilai kandungan bahan organik pada kawasan mangrove desa bedono termasuk tinggi. Hal ini sesuai dengan penelitian sebelumnya oleh Nugroho et al. (2013), bahwa hasil analisa bahan organik di kawasan mangrove Bedono nilai interprestasi untuk masing-masing sub stasiun bahwa secara keseluruhan tergolong dalam kategori tinggi pada masing-masing Sub Stasiun.

Bahan organik turun pada semua stasiun dikarenakan bahan organik ini dirombak lagi menjadi unsur unsur yang lebih kecil dan sederhana lagi seperti nitrit, nitrat, phospat, kalium, carbon dan yang lainnya. Hal ini diperkuat oleh Nugroho et al. (2013), bahwa semakin tinggi bahan organik maka kandungan P juga akan meningkat. Laju keluaran antara lain dipengaruhi oleh dekomposisi dan absorbsi dari tanaman mangrove itu sendiri. Bahan organik ini yang kemudian akan diurai oleh mikroorganisme menjadi mineral, diantaranya adalah $\mathrm{K}$, sehingga semakin tinggi kandungan bahan organiknya maka kandungan K juga akan meningkat.

Perbedaan nilai bahan organik juga dipengaruhi stasiun pengambilan sampel. Sehingga bahan organik yang terpakai untuk proses dekomposisi pada setiap stasiun berbedatergantung dari kerapatannya, apabila kerapatan mangrovenya tinggi maka nilai bahan organik juga tinggi. Hal ini diperkuat oleh Kushartono (2009), bahwa Tingginya bahan organik pada lapisan permukaan $(10 \mathrm{~cm})$ ini disebabkan karena produksi seresah dari bakau tinggi , dimana kerapatan tanaman juga tinggi.

Nilai kebutuhan oksigen berbeda pada perlakuan 1 dan 2. Perlakuan 1 hanya berisi air sehingga membutuhkan waktu yang lama untuk mencapai angka nol dan selisih nilai kadar oksigen setiap harinya hanya sedikit. Hal ini berbeda dengan perlakuan yang berisi air dan sedimen. Perlakuan nilai kadar oksigen cepat sekali mencapai angka nol dan selisisih nilai kadar oksigen setiap harinya terlihat banyak. Hal ini dikarenakan oksigen dalam air tidak hanya digunakan dalam air saja tetapi juga digunakan dalam sedimen untuk proses dekomposisi bahan organik sedimen. Kebutuhan oksigen yang dibutuhkan setiap harinya selalu naik. Terutama pada perlakuan 2, karena setiap hari terjadi proses dekomposisi bahan organik sehingga oksigen yang dibutuhkan selalu bertambah.

Nilai kebutuhan oksigen sedimen tertinggi terdapat pada stasiun 1 dibanding kedua stasiun yang lain. Dimana pada stasiun 1 dan stasiun 2 oksigen habis pada waktu 66 jam, sedangkan stasiun 3 habis pada waktu 63 jam. Hal ini dikarenakan pada stasiun 1 dan 2 termasuk daerah yang lebat sehingga nilai bahan organiknya tinggi sehingga membutuhkan waktu yang lama untuk merombak bahan organik. Berbeda dengan stasiun 3 yang tidak terlalu lebat sehingga bahan organik tidak tinggi dan oksigen yang dibutuhkan tidak tidak terlalu banyak dan cepat habis. Hal ini diperkuat oleh Setiawan (2013), bahwa pada lokasi dengan tingkat ketebalan mangrovenya tinggi, memiliki bahan organik yang lebih besar dari pada lokasi yang tanpa terdapat mangrove. Dengan semakin melimpahnya bahan organik akan menunjukkan bahwa perairan tersebut termasuk perairan yang sehat karena bahan organik akan terdekomposisi dan selanjutnya menjadi makanan bagi mikroorganisme.

\section{b. Kellimpahan Koloni Bakteri}

Perhitungan koloni bakteri sampai dengan pengenceran ke tujuh. Stasiun 1 dan stasiun 3 memiliki jumlah koloni yang hampir sama dan jumlah koloni bakteri ini naik setiap harinya. Kenaikan jumlah koloni bakteri ini dikarenakan bakteri berkembang biak dengan cepat dan dalam jumlah yang banyak. Selian itu jumlah koloni bakteri juga berpengaruh terhadap berkurangnya bahan organik. Menurunnya bahan organik karena semakin banyaknya bakteri yang melakukan proses dekomposisi.

Proses dekomposisi berhubungan dengan ketersidaan oksigen dalam perairan. Karena oksigen merupakan salah satu faktor yang digunakan bakteri untu merombak bahan organik. Hal ini diperkuat oleh Wijiyono (2009), bahwa proses dekomposisi bakteri sangat dipengaruhi oleh kondisi lingkungan terutama ketersediaan oksigen terlarut khususnya bakteri aerobik. Dekomposisi oleh bakteri anaerob akan menghasilkan bahan-bahan yang dapat merugikan kehidupan organisme perairan.

\section{c. Varibel Fisika dan Kimia Air}

Temperatur saat penelitian didalam akuarium berkisar $27-32{ }^{\circ} \mathrm{C}$. Setiap hari temperatur menurun karena adanya perlakuan pada akuarium yaitu akuarium harus tertutup dengan plastik hitam sehingga minim cahaya matahari yang masuk menembus akuarium. Temperatur tersebut dapat membantu proses dekomposisi bahan organik. Hal ini diperkuat oleh Suprapto (2014), bahwa hasil pengukuran temperatur berkisar antara 27,7-28,9 ${ }^{\circ} \mathrm{C}$ yang menunjukkan bahwa lingkungan perairan sekitar muara masih menciri sebagai lingkungan alami yang mampu mendukung kinerja bakterial untuk proses dekomposisi, kinerja fitoplankton untuk menunjang produktivitas perairan, serta metabolisme normal ikan.

Salinitas saat penelitian didalam akuarium berkisar antara 25 - $30 \%$ o. Nilai salinitas ini tidak berbeda jauh dengan nilai salinitas pada lingkungan mangrove sebenarnya saat pengambilan sampel yaitu $26-28 \%$. Salinitas juga berpengaruh terhadap proses dekomposisi oleh bakteri. Salinitas merupakan salah satu faktor pembatas bakteri dalam mendekomposisi bahan organik. Semakin tinggi salinitas maka kinerja bakteripun berbeda. Hal ini diperkuat oleh Wijiyono (2009), bahwa bertambahnya salinitas akan memberikan efek negatif terhadap kelimpahan dan keanekaragaman bakteri. Tingginya tingkat salinitas merupakan faktor pembatas yang 
mengontrol jumlah koloni bakteri yang menyebabkan rendahnya tingkat aktivitas bakteri akibat terjadinya shock osmotic atau toksik.

Nilai $\mathrm{pH}$ yang terukur didalam akuarium yaitu berkisar anatara $7-8$. Nilai $\mathrm{pH}$ ini juga sama dengan lingkungan mangrove sebenaranya saat pengambilan sampel, yaitu berkisar $7-8$. Nilai $\mathrm{pH}$ tersebut turut berperan dalam kehidupan mikroorganisme tanah termasuk bakteri. Hal ini diperkuat oleh Irfan (2014), bahwa pH sangat berperan pada ketersediaan nutrisi untuk mikroorganisme tanah dan juga berperan pada daya kerja enzim yang dihasilkan oleh mikroorganisme. $\mathrm{pH}$ optimum bagi kebanyakan bakteri adalah minimum 4 dan maksimum adalah 9, namun beberapa spesies dapat tumbuh dalam keadaan masam atau basa. Selain itu $\mathrm{pH}$ sangat mempengaruhi aktivitas dan perkembangan jasad renik tanah serta aktivitas jasad renik akan menurun seiring dengan menurunnya $\mathrm{pH}$. Namun nilai $\mathrm{pH}$ yang didapat adalah 8 atau sudah termasuk basa sehingga jumlah koloni bakteri akan bertambah.

\section{KESIMPULAN}

Kesimpulan yang didapat dari penelitian yang telah dilakukan adalah kebutuhan oksigen sedimen untuk proses dekomposisi bahan organik yaitu rata - rata kebutuhan oksigen sedimen tertinggi pada stasiun 1 yaitu 2,55, dengan efektifitas habis dalam waktu 66 jam. Rata - rata kebutuhan oksigen sedimen pada stasiun 2 yaitu 1,58 dengan efektifitas habis dalam waktu 66 jam. Rata - rata kebutuhan oksigen sedimen pada stasiun 3 yaitu 1,47 dengan efektifitas habis dalam waktu 63 jam.

\section{UCAPAN TERIMAKASIH}

Ucapan terimakasih ditujukan kepada Dr. Ir. Agung Suryanto, MS, Dr. Ir. Bambang Sulardiono, M.Si, dan Dr. Ir. Suryanti, M.Pi selaku dosen penguji yang telah bersedia memberikan masukan dan sarannya dalam pembuatan skripsi.

\section{DAFTAR PUSTAKA}

Hadinafta, R. 2009. Analisis Kebutuhan Oksigen untuk Dekomposisi Bahan Organik di Lapisan Dasar Perairan Estuari Sungai Cisadane, Tangerang. [Skripsi]. Fakultas Perikanan dan Ilmu Kelautan, Institut Pertanian Bogor, Bogor, 39 hlm.

Irfan, M. 2014. Isolasi Dan Enumerasi Bakteri Tanah Gambut Di Perkebunan Kelapa Sawit PT Tambang Hijau Kecamatan Tambang Kabupaten Kampar. Jurnal Agroteknologi. Vol 5 (1) : 1 - 8

Kushartono, E.W. 2009. Beberapa Aspek Bio-Fisika Kimia Tanah di Daerah Manrove Desa Pasar Banggi Kabupaten Rembang. Ilmu Kelautan., 14(2): 76-83.

MacPherson, T.A. 2003. Sediment Oxygen Demand and Biochemical Oxygen Demand Patterns of Oxygen Depletion in Tidal Creek Sites. [Thesis]. Program in Marine Science, University of North Carolina, Wilmington, $55 \mathrm{p}$.

Nugroho, R.A., S. Widada dan R. Pribadi. 2013. Studi Kandungan Bahan Organik dan Mineral (N,P,K,Fe dan $\mathrm{Mg}$ ) Sedimen di Kawasan Mangrove Desa Bedono Kecamatan Sayung Kabupaten Demak. Journal of Marine Research, Vol 2 (1) : 62 - 70

Putri, M.A. 2015. Rasio C/N Terhadap Bahan Organik dan Total Bakteri pada Sedimen di Habitat Rajungan (Portunus pelagicus Linn., 1758) Pantai Betahwalang, Kabupaten Demak. [Skripsi]. Fakultas Perikanan dan Ilmu Kelautan, Universitas Diponegoro, Semarang

Roswati, S., M.R. Muskananfola, dan P.W. Purnomo. 2014. Tingkat Sedimentasi di Muara Sungai Wedung Kecamatan Wedung, Demak. Journal of Maquares, Vol 3 (2) : 129-137

Setiawan, H. 2013. Status Ekologi Hutan Mangrove Pada Berbagai Tingkat Ketebalan (Ecological Status of Mangrove Forest at Various Thickness Levels). Jurnal Penelitian Kehutanan Wallacea, Vol 2 (2) : $104-120$

Setyawan, A. Dwi dan K. Winarno. 2006. Permasalahan Konservasi Ekosistem mangrove di Pesisir Kabupaten Rembang, Jawa Tengah. Biodiversitas, Vol 7 (2) : 159-163

Siska, M. Dan R. Salam. 2012. Desain Eksperimen Pengaruh Zeloit Terhadap Penurunan Limbah Kadmium (Cd). Jurnal Ilmiah Teknik Industri, Vol 11 (2) : 173 - 184

Suprapto, D., P.W. Purnomo dan B. Sulardiono. 2014. Analisis Kesuburan Perairan Berdasarkan Hubungan Fisika Kimia Sedimen Dasar Dengan $\mathrm{NO}_{3}-$ Dan $\mathrm{PO}_{4}-\mathrm{P}$ Di Muara Sungai Tuntang Demak. Journal of Fisheries Science and Technology, Vol 10 (1) : 56 - 61

Wijiyono. 2009. Keanekaragaman Bakteri Serasah Daun Avicennia marina Yang Mengalami Dekomposisi Pada Berbagai Tingkat Salinitas Di Teluk Tapian Nauli. [Tesis]. Sekolah Pascasarjana, Universitas Sumatera Utara, Medan, 65 hlm

Zamroni, Y. dan I.S. Rohyani. 2008. Produksi Serasah Hutan Mangrove di Perairan Pantai Teluk Sepi, Lombok Barat. Biodiversitas, Vol 9 (4) : 284-287

\footnotetext{
${ }^{\circledR}$ Copyright by Management of Aquatic Resources (MAQUARES)
} 